Gut, 1980, 21, 962-964

\title{
Portal hypertension in fulminant viral hepatitis
}

\author{
D LEBREC,* O NOUEL, J BERNUAU, B RUEFF, AND J P BENHAMOU \\ From the Unité de Recherches de Physiopathologie Hépatique, (INSERM), Hôpital Beaujon, Clichy, France
}

SUMMARY The gradient between wedged and free hepatic venous pressures was measured in 10 unselected adult patients suffering from fulminant viral hepatitis. The gradient was increased in all the studied patients, ranging from 0.9 to $2 \cdot 1 \mathrm{kPa}$; this finding indicates that portal hypertension was present in all these cases. Ascites was present in all the five patients having a gradient above $1.5 \mathrm{kPa}$ and affected only two of the five patients having a gradient below $1.5 \mathrm{kPa}$; this observation suggests that portal hypertension plays a role in the mechanism of ascites in fulminant viral hepatitis. Portal hypertension in fulminant viral hepatitis is likely to be the consequence of an intrahepatic block due to massive necrosis of the liver cells.

It is generally admitted that portal hypertension may develop in patients with chronic liver disease and is absent in patients with acute liver disease. ${ }^{1}$ The purpose of this investigation is to show that portal hypertension (1) is a common complication of fulminant viral hepatitis, (2) is, at least in part, responsible for ascites in these patients, and (3) could be the consequence of an intrahepatic block determined by massive necrosis of the liver cells.

\section{Methods}

PATIENTS

Ten unselected adult patients, consecutively admitted to Hôpital Beaujon in 1978 for fulminant viral hepatitis, were investigated. The diagnosis of fulminant viral hepatitis was based on clinical manifestations, liver function tests, and hepatic histology: jaundice and hepatic encephalopathy were present in all our patients; the delay between the onset of jaundice and the onset of hepatic encephalopathy ranged from three to 34 days (Table); serum transaminases were high and prothrombin level was below $20 \%$ of normal in all cases; histological examination of a liver specimen taken by transvenous liver biopsy ${ }^{2}$ showed normal architecture and massive necrosis of the hepatic cells in all cases. Fulminant hepatitis was attributed to acute viral infection because of the absence of past history of liver disease and of the absence of other factors, drugs in particular, known to induce acute liver lesions; hepatitis B surface

*Address for reprint requests: Dr D Lebrec, Unité de Recherches de Physiopathologie Hépatique, Hôpital Beaujon, 92118 Clichy, France.

Received for publication 15 June 1980 antigen was demonstrated in three patients. Moderate ascites developed in seven patients, one to 14 days after the onset of encephalopathy; protein concentration in the ascitic fluid ranged from 5 to $15 \mathrm{~g} / 1$. Among our 10 patients, six died of severe hepatic failure; the four surviving patients were reexamined six months after the episode of fulminant hepatitis and had no clinical manifestations or abnormalities of liver function tests indicating portal hypertension or liver disease.

Before the insertion of the needle for transvenous liver biopsy, wedged and free hepatic venous pressures were measured; wedging was confirmed by the absence of reflux after injection of $2 \mathrm{ml}$ of contrast into the catheter. This procedure was performed one to 21 days after the onset of hepatic encephalopathy (Table). The normal values for the gradient between wedged and free hepatic pressures range from $0 \cdot 1$ to $0.5 \mathrm{kPa}$ in this laboratory.

\section{Results}

The values for the gradient between wedged and free hepatic venous pressures were above $0.6 \mathrm{kPa}$ in all our 10 patients (Table). All the five patients with a value for the gradient above $1.5 \mathrm{kPa}$ and only two of the five others with a value for the gradient below this level had ascites.

\section{Discussion}

The main finding of this investigation is the high prevalence of an increased value for the gradient between wedged and free hepatic venous pressures in our patients with fulminant viral hepatitis. In the 
Table Clinical course and gradient between wedged and free hepatic venous pressures in 10 patients with fulminant viral hepatitis

\begin{tabular}{|c|c|c|c|c|c|}
\hline \multirow{2}{*}{$\begin{array}{l}\text { Patient } \\
\text { No. }\end{array}$} & \multicolumn{2}{|l|}{ Delay between onset of: } & \multirow{2}{*}{$\begin{array}{l}\text { Gradient between wedged and } \\
\text { free hepatic venous pressures* } \\
(k P a)\end{array}$} & \multirow[t]{2}{*}{ Ascites } & \multirow[t]{2}{*}{ Outcome } \\
\hline & $\begin{array}{l}\text { Jaundice and } \\
\text { hepatic encephalopathy } \\
\text { (days) }\end{array}$ & $\begin{array}{l}\text { Hepatic encephalopathy and } \\
\text { hepatic venous catheterisation } \\
\text { (days) }\end{array}$ & & & \\
\hline 1 & 24 & 2 & 0.9 & Absent & Death \\
\hline 2 & 3 & 1 & 0.9 & Absent & Recovery \\
\hline 3 & 14 & 3 & $1 \cdot 1$ & Present & Death \\
\hline 4 & 23 & 1 & $1 \cdot 1$ & Present & Death \\
\hline 5 & 3 & 4 & $1 \cdot 3$ & Absent & Recovery \\
\hline 6 & 5 & 12 & $1 \cdot 7$ & Present & Death \\
\hline 7 & 15 & 21 & 1.7 & Present & Recovery \\
\hline 8 & 24 & 6 & 1.7 & Present & Recovery \\
\hline 9 & 14 & 2 & $2 \cdot 1$ & Present & Death \\
\hline 10 & 27 & 15 & $2 \cdot 1$ & Present & Death \\
\hline
\end{tabular}

Normal range: $0 \cdot 1-0.5 \mathrm{kPa}$.

absence of obstruction of the portal vein or intrahepatic portal venules, the gradient between wedged and free hepatic venous pressures closely reflects portal venous pressure. ${ }^{3}$ The increased value for the gradient in all our patients therefore indicates that portal hypertension is a common, if not constant, consequence of fulminant viral hepatitis. The degree of portal hypertension was moderate in some of our patients in whom the value for the gradient was below $1.5 \mathrm{kPa}$; however, hepatic vein catheterisation was performed on only one occasion in our patients, and it is conceivable that the value for the gradient could have been higher in the course of the disease. Portal hypertension seems to be a complication of fulminant hepatitis, and not of acute hepatitis in general: in benign viral hepatitis, it has been shown that portal venous pressure is either normal or, in a few cases, slightly raised. ${ }^{4-7}$

Ascites, although regarded as an infrequent feature of fulminant hepatitis, was common in our patients. The observation that ascites was present in all of our patients with a markedly increased gradient between wedged and free hepatic venous pressures and only in a part of our patients with a moderately augmented gradient suggests that portal hypertension is a factor in the development of ascites. The low protein content of ascitic fluid is consistent with this mechanism for ascites in our patients. Sodium retention, which has been reported as affecting most of the patients with fulminant hepatitis, ${ }^{8}$ could be a contributory factor in the development of ascites in these patients.

Portal hypertension in fulminant hepatitis might be the consequence of an intrahepatic block related to massive necrosis of the liver cells: (1) portal hypertension is common in patients with fulminant hepatitis in whom liver necrosis is extensive, whereas it is absent or mild in patients with benign viral hepatitis $^{4-7}$ in whom liver necrosis is limited;
(2) hepatic lesions other than liver cell necrosis, fibrosis in particular, were absent in our patients; (3) in our surviving patients, the absence of manifestations of portal hypertension suggests that portal venous pressure has returned to normal after disappearance of liver cell necrosis. The mechanism for the intrahepatic block could be the sinusoids being disrupted and/or obstructed by necrotic hepatocytes, or the hepatic vascular bed being reduced by liver atrophy, a common consequence of fulminant hepatitis. ${ }^{9}$ High cardiac output, which has been reported in fulminant hepatitis, ${ }^{10}$ might result in an increased hepatic blood flow and thus exaggerate portal hypertension in these patients.

\section{References}

'Sherlock S. Portal circulation and portal hypertension. Gut 1978; 19: 70-83.

${ }^{2}$ Lebrec D, Degott C, Rueff B, Benhamou JP. Transvenous (transjugular) liver biopsy. An experience based on 100 biopsies. Am J Dig Dis 1978; 23: 302-4.

${ }^{3}$ Boyer TD, Triger DR, Horisawa M, Redeker AG, Reynolds TB. Direct transhepatic measurement of portal vein pressure using a thin needle. Comparison with wedged hepatic vein pressure. Gastroenterology 1977; 72: 584-9.

${ }^{4}$ Preisig R, Rankin JG, Sweeting J, Bradley SE. Hepatic hemodynamics during viral hepatitis in man. Circulation 1966; 34: 188-97.

${ }^{5}$ Lundbergh P, Strandell T. Changes in hepatic circulation at rest, during and after exercise in young males with infectious hepatitis compared with controls. Acta Med Scand 1974; 196: 315-25.

${ }^{6}$ Reichman S, Davis WD. The splenic approach to the portal circulation. Intrasplenic and intrahepatic tissue pressure measurements in acute and convalescent hepatitis. Gastroenterology 1957; 33: 609-15.

${ }^{7}$ Haerter W, Palmer ED. Portal hypertension with esophageal varices in acute infectious hepatitis: further observations. Am J Med Sci 1959; 237: 596-9. 
${ }^{8}$ Wilkinson SP, Arroyo VA, Moodie H, Blendis LM, Williams R. Abnormalities of sodium excretion and other disorders of renal function in fulminant hepatic failure. Gut 1976; 17: 501-5.

${ }^{9}$ Rueff B, Benhamou JP. Acute hepatic necrosis and fulminant hepatic failure. Gut 1973; 14: 805-15.

${ }^{10}$ Cohn JD, Greenspan M, Goldstein CR, Gudwin AL, Siegel JH, Del Guercio LR. Arteriovenous shunting in high cardiac output shock syndromes. Surg Gynecol Obstet 1968; 127: 282-8. 